\title{
Pomiar naprężeń własnych powłok metalicznych natryskiwanych termicznie
}

\author{
Measurement of residual stresses \\ in thermally sprayed metallic layers
}

\section{Streszczenie}

Przeprowadzono ocenę rozkładu naprężeń w natryskiwanych powłokach tytanowych i kompozytowych $\left(\mathrm{Al}_{2} \mathrm{O}_{3}+\mathrm{Ti}\right)$ na podłożach ceramicznych. Celem badań była weryfikacja wyników naprężeń otrzymanych na stanowisku pomiarowym do badania naprężeń metodą krzywizny wygięcia. Wyniki pomiarów zestawiono z naprężeniami obliczonymi metodą numeryczną (MES) dla analogicznych próbek i materiałów. Zbudowane stanowisko pomiarowe umożliwiło wstępną weryfikację obliczeń numerycznych, które udostępniają znacznie więcej danych o rozkładzie naprężeń na przekrojach próbek.
Abstract

The evaluation of residual stresses in thermally sprayed titanium and composite $\mathrm{Ti}+\mathrm{Al}_{2} \mathrm{O}_{3}$ coatings on ceramic substrates have been conducted. The main purpose of the research was to perform initial verification of stresses obtained by the curvature measurement of analyzed samples. The results has been compared to numerical simulations (FEM) of residual stresses in models reflected real coating/substrate samples. The built curvature measuring system allowed for initial verification of obtained results from numerical computations, which give us much more data about the distribution of residual stresses across the coating and substrate.

\section{Wstęp}

Ocena naprężeń w natryskiwanych termicznie powłokach metalicznych i ceramicznych decyduje o trwałości eksploatacyjnej nanoszonych powłok. Żadna metoda oceny stanu naprężeń, nie zapewnia jednak w $100 \%$ uzyskanie rzeczywistych wyników. Stąd, do wyznaczania naprężeń własnych w układzie powłoka-podłoże wykorzystuje się często kilka różnych metod, które wzajemne uzupełniając się, umożliwiają na weryfikację wyników. W celu wykonania zbudowano stanowisko pomiarowe do oceny stanu naprężeń metodą krzywizny $w$ natryskiwanych termicznie powłokach. Umożliwia ona pomiar krzywizny wygięcia układu powłoka-podłoże, na podstawie którego można wyznaczyć średnie naprężenie własne w powłoce. Do

Dr inż. Tomasz Chmielewski, dr hab. inż. Dariusz Golański, mgr inż. Grzegorz Gontarz - Politechnika Warszawska. oceny zmian naprężeń własnych na przekroju powłokapodłoże zastosowano analizę numeryczną (MES) modelu odzwierciedlającego badane próbki. Metoda pomiaru naprężeń została zweryfikowana.

\section{Naprężenia w układzie powłoka-podłoże}

W procesie natryskiwania cieplnego materiału powłokowego (Ti) na podłoże ceramiczne $\left(\mathrm{Al}_{2} \mathrm{O}_{3}\right)$ uzyskuje się dość cienkie warstwy $(0,05 \div 0,2 \mathrm{~mm})$ dobrze związane z podłożem. Nanoszenie grubszych powłok wiąże się ze wzrostem naprężeń, który często prowadzi do delaminacji powłoki po procesie natryskiwania, stąd znaczenie naprężeń własnych w tego typu układach jest bardzo duże.

Naprężenia własne $\left(\delta_{\text {res }}\right)$ w natryskiwanych powłokach są sumą naprężeń pochodzących od chłodzenia ciekłych kropli materiału powłokowego $\left(\delta_{q}\right)$ oraz 
naprężeń w czasie chłodzenia powstałej powłoki i podłoża jako całości $\left(\delta_{c}\right)$ :

$$
\sigma_{r e s}=\sigma_{q}+\sigma_{c}
$$

gdzie:

$$
\begin{gathered}
\sigma_{q}=\alpha_{c}\left(T_{m}-T_{s}\right) E_{c} \\
\sigma_{c}=\left(\alpha_{c}-\alpha_{s}\right) \frac{E_{c}}{1-v} \Delta T
\end{gathered}
$$

przy czym: $\alpha_{c s}$ - współczynnik rozszerzalności cieplnej powłok i podłoża; $T_{m}, T_{s}$ - temperatura topnienia materiału powłoki, temperatura podłoża; $\Delta \mathrm{T}$ - różnica temperatury; $\mathrm{E}_{\mathrm{c}}$ - moduł Younga powło$\mathrm{ki}, \mathrm{v}$ - liczba Poissona.

Układ powłoka-podłoże możemy rozpatrywać jako połączenie dwóch płyt (rys. 1a). W wyniku różnego skurczu poprzecznego obu materiałów, powstającego w procesie ich chłodzenia, powstaje pewne niedopasowanie płyt $\Delta e$ (rys. 1b), przy czym układ sił poprzecznych musi być w równowadze dla całego układu (rys. 1c). Efektem końcowym jest zatem wygięcie płyt związane z powstającymi momentami gnącymi $M$ (rys. 1d) i opisane krzywizną wygięcia $K$.

Clyne [1] opisał w sposób analityczny powyższy model, uzyskując rozwiązanie umożliwiające wyznaczenie naprężeń na kierunku $x$ w powłoce i podłożu: - naprężenie na powierzchni górnej powłoki:

$$
\left.\sigma_{c}\right|_{y=h c}=-\Delta \varepsilon\left(\frac{E_{c}^{\prime} h_{s} E_{s}^{\prime}}{h_{c} E_{c}^{\prime}+h_{s} E_{s}^{\prime}}\right)+E_{c}^{\prime} \kappa\left(h_{c}-\delta\right)
$$

- naprężenie na powierzchni dolnej powłoki:

$$
\left.\sigma_{c}\right|_{y=0}=-\Delta \varepsilon\left(\frac{E_{c}^{\prime} h_{s} E_{s}^{\prime}}{h_{c} E_{c}^{\prime}+h_{s} E_{s}^{\prime}}\right)-E_{c}^{\prime} \kappa \delta
$$

- naprężenie na powierzchni górnej podłoża:

$$
\left.\sigma_{s}\right|_{y=0}=\Delta \varepsilon\left(\frac{E_{c}^{\prime} h_{s} E_{s}^{\prime}}{h_{c} E_{c}^{\prime}+h_{s} E_{s}^{\prime}}\right)-E_{s}^{\prime} \kappa \delta
$$

- naprężenie na powierzchni dolnej podłoża:

$$
\left.\sigma_{s}\right|_{y=-h s}=\Delta \varepsilon\left(\frac{E_{c}^{\prime} h_{s} E_{s}^{\prime}}{h_{c} E_{c}^{\prime}+h_{s} E_{s}^{\prime}}\right)-E_{s}^{\prime} \kappa\left(h_{s}+\delta\right)
$$

gdzie: $\delta_{c, s}-$ naprężenie w powłoce (c) i podłożu (s); $\Delta \varepsilon=\left(\alpha_{s}-\alpha_{c}\right)$ $\Delta T, \alpha_{c, s}-$ współczynnik rozszerzalności cieplnej powłoki i podłoża, $\Delta \mathrm{T}$ - różnica temperatury; $\mathrm{E}_{\mathrm{c}}{ }^{\prime}=\mathrm{E}_{\mathrm{c}} /\left(1-\mathrm{v}_{\mathrm{c}}\right), \mathrm{E}_{\mathrm{s}}{ }^{\prime}=\mathrm{E}_{\mathrm{s}} /\left(1-\mathrm{v}_{\mathrm{s}}\right) ; \mathrm{h}_{\mathrm{c}, \mathrm{s}}-$ grubość powłoki, podłoża; $E_{c s}$ - moduł Younga powłoki, podłoża, $K$ - krzywizna wygięcia (1/r); $\delta^{c, s}-$ zmierzone ugięcie układu (rys. 2). a)

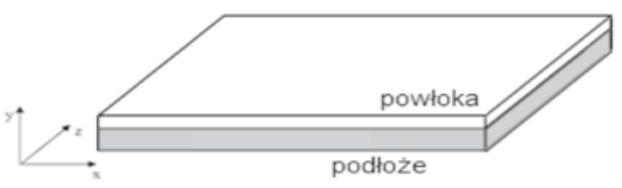

b)

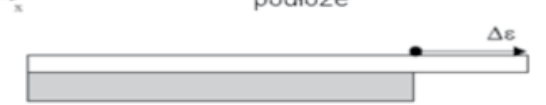

c)

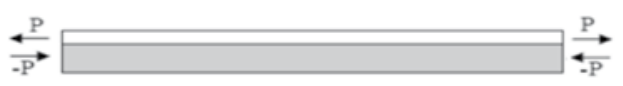

d)

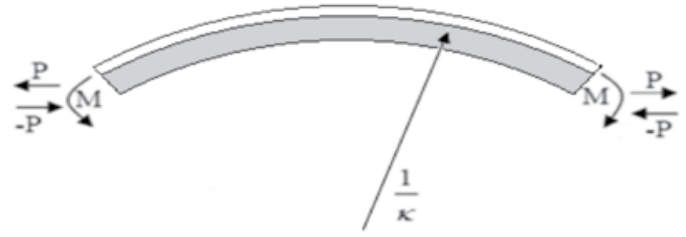

Rys. 1. Schemat powstawania wygięcia w układzie dwóch płyt opisujących powłokę i podłoże

Fig. 1. The scheme of deflection of two plates representing coating and substrate

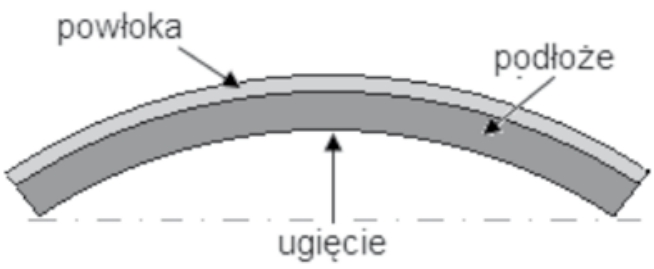

Rys. 2. Ugięcie podłoża z powłoką po natryskiwaniu

Fig. 2. Coating and substrate deflection after thermal spraying

Krzywiznę wygięcia K można wyznaczyć z następującej zależności:

$$
\kappa=\frac{6 E_{c} E_{s}\left(h_{c}+h_{s}\right) h_{c} h_{s} \Delta \varepsilon}{E_{c}^{2} h_{c}^{4}+4 E_{c} h_{c}^{3} h_{s}+6 E_{c} E_{s} h_{c}^{2} h_{s}^{2}+4 E_{c} E_{s} h_{c} h_{s}^{3}+E_{s}^{2} h_{s}^{4}}
$$

Najbardziej znana teoria związana z oceną naprężeń przez pomiar krzywizny wygięcia oparta jest na równaniu Stoneya [2, 3]:

$$
\sigma=\frac{1}{6} \frac{E_{s}}{\left(1-v_{s}\right)} \frac{h_{s}^{2}}{h_{c}}\left(\frac{1}{r_{2}}-\frac{1}{r_{1}}\right)
$$

gdzie: $r_{1}$ i $r_{2}$ są promieniami krzywizny podłoża przed nałożeniem $\left(r_{1}\right)$ i po nałożeniu powłoki $\left(r_{2}\right)$.

Jest ona ważna przy założeniu, że grubość powłoki jest dużo mniejsza od grubości podłoża. W przeciwnym wypadku konieczna jest modyfikacja równania Stoneya, tak aby uwzględniała porównywalne grubości warstw. W takim układzie równanie Stoneya ulegnie modyfikacji do następującej postaci [4]:

$$
\sigma=\frac{1}{6} \frac{E_{s}}{\left(1-v_{s}\right)} \frac{h_{s}^{2}}{h_{c}}\left(\frac{1}{r_{2}}-\frac{1}{r_{1}}\right)\left[1+\left(4 \frac{E_{c}\left(1-v_{s}\right)}{E_{s}\left(1-v_{c}\right)}-1\right) \frac{h_{s}}{h_{c}}\right]
$$




\section{Przyrząd do badania wygięcia podłoża z powłoką po procesie natryskiwania}

Do badania wygięcia oraz naprężeń własnych w natryskiwanych powłokach skonstruowano i zbudowano specjalny przyrząd (rys. 3a). Składa się on ze sztywnego statywu, na którym zamocowano płytki podkładowe i obciążające oraz kołki oporowe i ustalające. $\mathrm{Na}$ dole przyrządu zamocowany został cyfrowy czujnik zegarowy (dokładność $0,001 \mathrm{~mm}$ ) do pomiaru wygięcia płytki.

Badaną próbkę podłoża przeznaczoną do natryskiwania umieszczano na trzech kołkach podporowych i obciążano z drugiej strony płytką przez trzy kołki (rys. 3b). Do tak ustawionej płytki materiału podłoża kalibrowano wskazanie czujnika do wartości 0 . Po procesie próbkę podłoża z powłoką umieszczano ponownie w przyrządzie stroną nienatryskiwaną ustawioną w kierunku końcówki pomiarowej czujnika i po ustaleniu pozycji dokonywano ponownego odczytu wskazania czujnika, który rejestrował ugięcie płytki w środku jej długości.
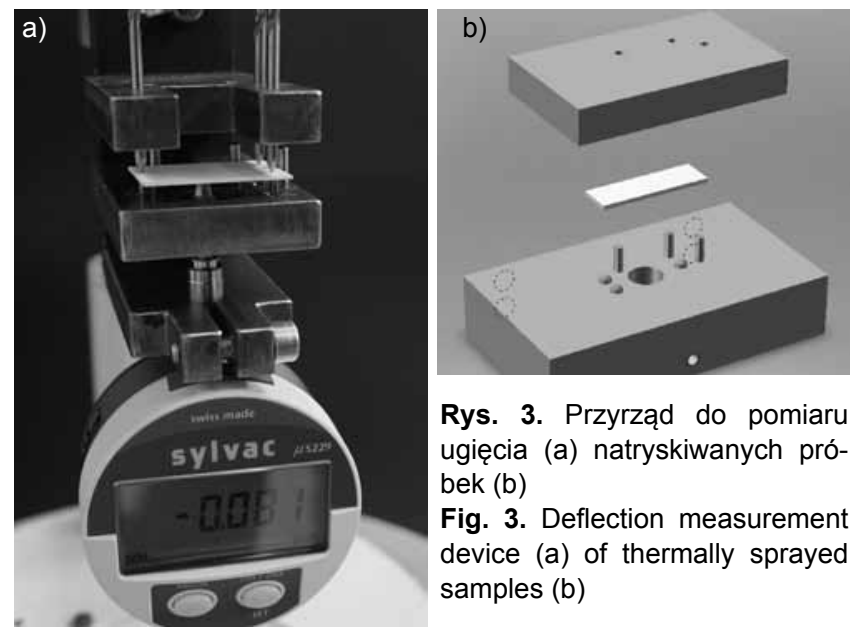

Rys. 3. Przyrząd do pomiaru ugięcia (a) natryskiwanych próbek (b)

Fig. 3. Deflection measurement device (a) of thermally sprayed samples (b)

\section{Próby natryskiwania}

W celu oceny wygięcia oraz pomiaru naprężeń własnych przeprowadzono próby natryskiwania powłok tytanowych oraz kompozytowych na podłoże ceramiki $\mathrm{Al}_{2} \mathrm{O}_{3}$. Taki zestaw materiałów (tytan, $\mathrm{Al}_{2} \mathrm{O}_{3}$ ) o znacznie zróżnicowanych właściwościach cieplno-fizycznych powinien zapewnić odpowiedni poziom wygięcia próbki po procesie natryskiwania. Podłoże ceramiczne $\left(\mathrm{Al}_{2} \mathrm{O}_{3}\right)$ miało kształt płytki o wymiarach $30 \times 20 \times 0,6 \mathrm{~mm}$ (rys. 4).

Natryskiwanie podłoża metodą płomieniową za pomocą palnika do natryskiwania CastoDyn DS8000 (rys. 4), wykonano przy parametrach procesu zamieszonych w tablicy I.

Palnik był prowadzony ręcznie ruchem oscylacyjnym od lewej do prawej strony próbki. Liczba przejść
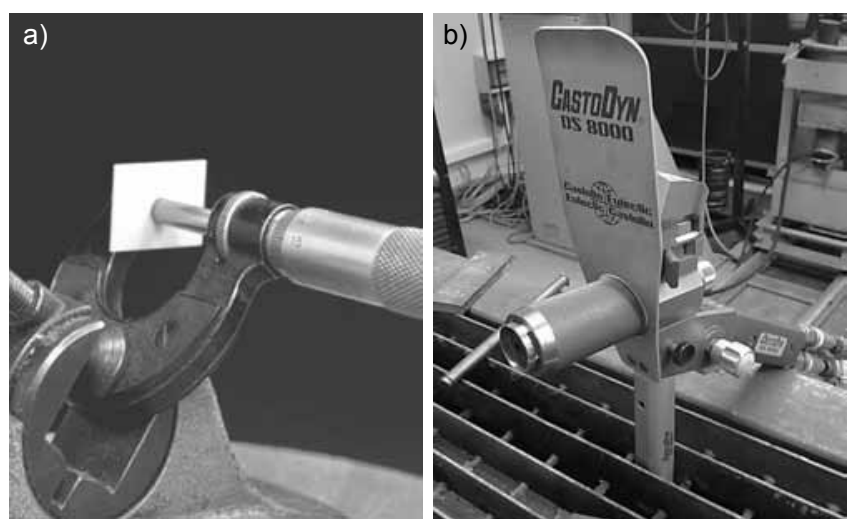

Rys. 4. Kształt podłoża ceramicznego $\mathrm{Al}_{2} \mathrm{O}_{3}$, a) do natryskiwania, b) palnik do natryskiwania płomieniowego DS8000

Fig. 4. a) The geometry of ceramic substrate for thermal spraying: b) DS8000 flame spraying gun

Tablica I. Parametry procesu natryskiwania płomieniowego Table I. The flame spraying parameters

\begin{tabular}{|l|c|c|}
\hline \multicolumn{1}{|c|}{ Materiał powłokowy } & $\mathrm{Ti}$ & $\mathrm{Ti}^{\prime} \mathrm{Al}_{2} \mathrm{O}_{3}$ \\
\hline Ciśnienie tlenu, bar & 3,0 & 3,0 \\
\hline Ciśnienie acetylenu, bar & 0,7 & 0,65 \\
\hline Ciśnienie powietrza, bar & 2,0 & 2,5 \\
\hline $\begin{array}{l}\text { Odległość palnika } \\
\text { od powierzchni natryskiwanej, } \mathrm{mm}\end{array}$ & 200,0 & 200,0 \\
\hline Prędkość przesuwu palnika, $\mathrm{mm} / \mathrm{min}$ & $200 \div 250$ & $200 \div 250$ \\
\hline
\end{tabular}
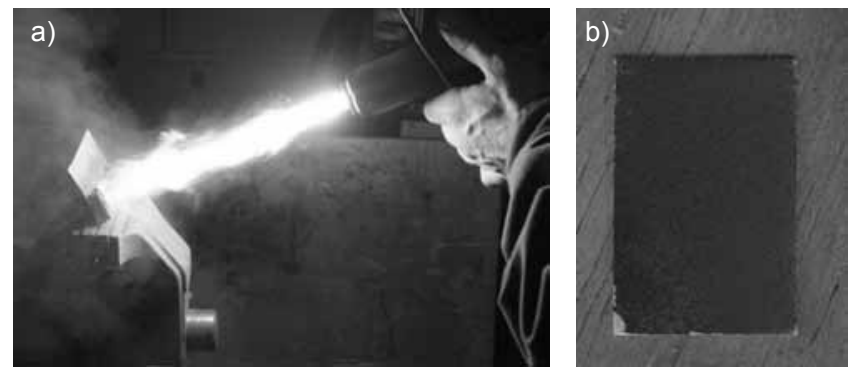

Rys. 5. Natryskiwanie tytanu na podłoże ceramiczne: a) przenoszenie cząstek tytanu, b) widok powłoki

Fig. 5. Thermal spraying of titanium onto ceramic substrate: a) the transport of titanium particle towards substrate, b) the view of thermally sprayed surface

była zmienna, zależna od oczekiwanej grubości powłoki. Na rysunku 5 pokazano zdjęcia z procesu natryskiwania oraz widok powierzchni próbki po natryskiwaniu tytanem. Przed natryskiem podłoże było wstępnie podgrzewane do ok. $120^{\circ} \mathrm{C}$.

\section{Wyznaczanie naprężeń własnych w natryskiwanych powłokach}

\section{Powłoki tytanowe}

Przeprowadzono obliczenia naprężeń własnych $\delta_{x}$ w powłoce $z$ wykorzystaniem równania Stoneya. Wartości krzywizny wygięcia próbek po natryskiwaniu obliczano na podstawie pomiaru ugięcia podłoża ceramicznego z wykorzystaniem zbudowanego przyrządu. 

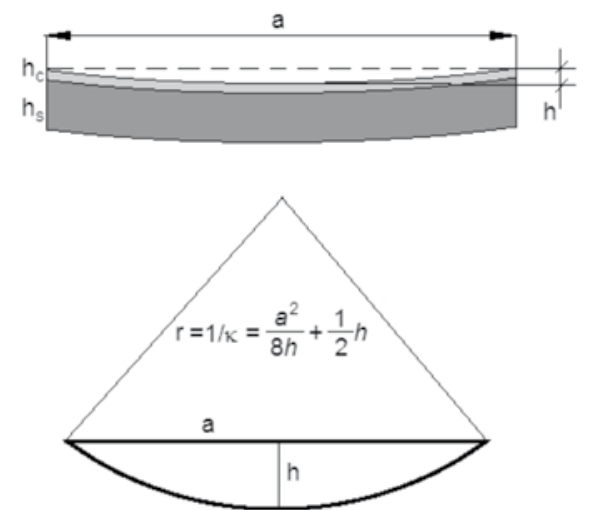

Rys. 6. Schemat geometrii powłoki po natrysku do wyznaczenia promienia krzywizny

Fig. 6. The scheme of geometry used for calculation of curvature radius

Tablica II. Wyniki pomiarów grubości, ugięcia próbki oraz wyznaczonych naprężeń własnych w powłokach Ti na podłożu $\mathrm{Al}_{2} \mathrm{O}_{3}$

Table II. The measurement results of thickness, samples deflection and calculated residual stresses in $\mathrm{Ti}$ coatings on $\mathrm{Al}_{2} \mathrm{O}_{3}$ substrate

\begin{tabular}{|c|c|c|c|c|}
\hline Nr próbki & $\begin{array}{c}\text { Grubość } \\
\text { powłoki } \\
\mathrm{h}_{\mathrm{c}}, \mu \mathrm{m}\end{array}$ & $\begin{array}{c}\text { Grubość } \\
\text { podłoża } \\
\mathrm{h}_{\mathrm{s}}, \mu \mathrm{m}\end{array}$ & $\begin{array}{c}\text { Ugięcie } \mathrm{h}, \\
\mu \mathrm{m}\end{array}$ & $\begin{array}{c}\text { Naprę- } \\
\text { żenie } \delta_{\mathrm{x}} \\
\mathrm{MPa}\end{array}$ \\
\hline 1 & 42 & 638 & 11 & 79,5 \\
\hline 2 & 52 & 638 & 13 & 75,5 \\
\hline 3 & 112 & 638 & 15 & 40,6 \\
\hline 4 & 122 & 638 & 16 & 39,8 \\
\hline 5 & 185 & 638 & 19 & 31,2 \\
\hline
\end{tabular}

Wielkość ugięcia była mierzona w połowie długości płytki ceramicznej dla różnych grubości nałożonych warstw. Wyniki pomiaru dla wybranych próbek z powłoką tytanową zamieszczono w tablicy II.

$\mathrm{Na}$ podstawie wielkości ugięcia $\mathrm{h}$ oraz odległości między podporami próbki $(\mathrm{a}=27 \mathrm{~mm}) \mathrm{z}$ zależności geometrycznych obliczono promień krzywizny $r$ natryskanej powłoki z podłożem (rys. 6).

Naprężenia własne w powłoce zgodnie $z$ równaniem Stoneya opisuje zależność (9). Człon $1 / r_{1}$ został pominięty ze względu na każdorazowe zerowanie czujnika dla podłoża ceramicznego bezpośrednio przed natryskiwaniem. Do obliczenia naprężeń przyjęto moduł Younga ceramiki $\mathrm{Al}_{2} \mathrm{O}_{3} \mathrm{E}_{\mathrm{s}}=320 \mathrm{GPa}$ oraz liczbę Poissona $v=0,22$. Obliczone wg równania Stoneya średnie naprężenia $\delta_{\mathrm{x}} \mathrm{w}$ powłoce tytanowej zestawiono w ostatniej kolumnie tablicy II.

\section{Powłoki kompozytowe $\mathrm{Ti}+\mathrm{Al}_{2} \mathrm{O}_{3}$}

W celu porównania wyników dla powłok tytanowych przeprowadzono próby natryskiwania dla powłok kompozytowych $\mathrm{Ti}+\mathrm{Al}_{2} \mathrm{O}_{3}$ z $30 \%$ zawartością fazy

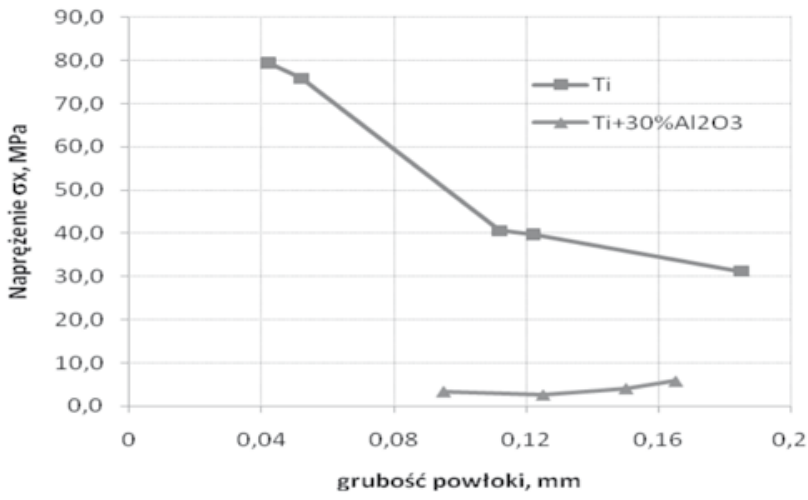

Rys. 7. Naprężenie własne $\delta_{x}$ w powłokach $\mathrm{Ti}$ oraz $\mathrm{Ti}+30 \% \mathrm{Al}_{2} \mathrm{O}_{3}$ obliczone na podstawie krzywizny wygięcia próbek po procesie natryskiwania w funkcji grubości powłoki

Fig. 7. The effect of substrate thickness on the residual stresses $\left(\delta_{x}\right)$ in $\mathrm{Ti}$ and $\mathrm{Ti}+30 \% \mathrm{Al}_{2} \mathrm{O}_{3}$ coatings calculated upon sample curvature measurements after thermal spraying

Tablica III. Wyniki pomiarów grubości, ugięcia próbki oraz wyznaczonych naprężeń własnych w powłokach $\mathrm{Ti}+30 \% \mathrm{Al}_{2} \mathrm{O}_{3}$ na podłożu $\mathrm{Al}_{2} \mathrm{O}_{3}$ Table III. The measurement results of thickness, samples deflection and calculated residual stresses in $\mathrm{Ti}+30 \% \mathrm{Al}_{2} \mathrm{O}_{3}$ coatings on $\mathrm{Al}_{2} \mathrm{O}_{3}$ substrate

\begin{tabular}{|c|c|c|c|c|}
\hline Nr próbki & $\begin{array}{c}\text { Grubość } \\
\text { powłoki } \\
\mathrm{h}_{\mathrm{c}}, \mu \mathrm{m}\end{array}$ & $\begin{array}{c}\text { Grubość } \\
\text { podłoża } \\
\mathrm{h}_{\mathrm{s}}, \mu \mathrm{m}\end{array}$ & $\begin{array}{c}\text { Ugięcie } \mathrm{h}, \\
\mu \mathrm{m}\end{array}$ & $\begin{array}{c}\text { Naprężenie } \\
\text { w powłoce } \\
\delta_{\mathrm{x}}, \mathrm{MPa}\end{array}$ \\
\hline 1 & 95 & 655 & 1 & 3,4 \\
\hline 2 & 125 & 655 & 1 & 2,6 \\
\hline 3 & 150 & 655 & 2 & 4,1 \\
\hline 4 & 165 & 638 & 3 & 5,8 \\
\hline
\end{tabular}

ceramicznej. Powłoka taka ma właściwości cieplno-fizyczne bardziej zbliżone do podłoża ceramicznego co powinno sprzyjać zmniejszeniu naprężeń własnych w powłoce. Natryskiwanie prowadzono w takich samych warunkach jak dla czystego tytanu. Grubości podłoża różniły się nieznacznie.

W tablicy III zestawiono wyniki pomiarów grubości i wygięcia próbek, a także obliczone na podstawie równania Stoneya naprężenia własne w powłoce $\mathrm{Ti}+30 \% \mathrm{Al}_{2} \mathrm{O}_{3}$. Zanotowano bardzo niskie wartości ugięcia podłoża, co świadczy o znacznie niższym poziomie naprężeń.

Porównawczy wykres naprężeń własnych pomiędzy powłokami tytanowymi oraz kompozytowymi przedstawiono na rysunku $7, z$ którego widać, że średnie naprężenie $w$ powłokach kompozytowych $\mathrm{Ti}+30 \% \mathrm{Al}_{2} \mathrm{O}_{3}$ jest zdecydowanie niższe w porównaniu do powłok tytanowych, przy czym widoczny jest spadek wartości tego naprężenia w powłoce tytanowej ze wzrostem grubości powłoki. Dla powłok kompozytowych zmiany średniego naprężenia w powłoce podlegają niezbyt dużym wahaniom w zakresie zmierzonych grubości powłok. 


\section{Analiza numeryczna naprężeń własnych w powłokach tytanowych i kompozytowych}

W pracy podjęto próbę porównania stanu naprężeń własnych w powłokach tytanowych nanoszonych na podłoże ceramiki $\mathrm{Al}_{2} \mathrm{O}_{3}$. Ze względu na różnicę właściwości cieplno-fizycznych i mechanicznych pomiędzy tytanem a ceramiką należy spodziewać się występowania w powłoce i podłożu wysokich naprężeń ze szczególnym uwzględnieniem obszaru granicy tytan-ceramika. Dlatego porównano rozkłady naprężeń własnych dla kilku wybranych konfiguracji układu powłoka-podłoże, w celu wstępnego określenia ich wpływu na wielkość powstających naprężeń własnych.

Stan naprężeń w przekroju poprzecznym powłoki i podłoża oceniono przez modelowanie naprężeń własnych w układzie powłoka tytanowa (kompozytowa)-podłoże $\mathrm{Al}_{2} \mathrm{O}_{3}$. Model numeryczny oparty na metodzie elementów skończonych odzwierciedlał geometrię i wymiary natryskiwanych wcześniej próbek (rys. 8). Ze względu na symetrię osiową analizowano tylko prawą połowę modelu. Zastosowano ośmiowęzłowe elementy czworokątne. Powstała siatka elementów zagęszczona została w obszarze spodziewanej koncentracji naprężeń wzdłuż granicy powłoka-podłoże. Dane materiałowe dla ceramiki $\mathrm{Al}_{2} \mathrm{O}_{3}$ i tytanu przyjęto na podstawie dostępnych źró-

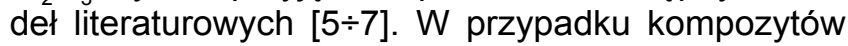
$\mathrm{Ti}+30 \% \mathrm{Al}_{2} \mathrm{O}_{3}$ właściwości efektywne obliczano na podstawie tzW. reguły mieszanin (moduł Younga, liczba Poissona, współczynnik rozszerzalności cieplnej). W czasie natryskiwania temperatura podłoża ceramicznego wstępnie wynosiła ok. $100 \div 150^{\circ} \mathrm{C}$, a po zakończeniu natryskiwania wzrosła do $160 \div 220^{\circ} \mathrm{C}$. Wobec niemożności precyzyjnego pomiaru temperatury powłoki przyjęto, że naprężenia własne w powłoce i podłożu powstają $w$ czasie równomiernego spadku temperatury w całym modelu w zakresie temperatury $200 \div 20^{\circ} \mathrm{C}$. Przyjęty zakres obciążenia cieplnego ma charakter umowny, aby umożliwić porównanie wyników naprężeń pomiędzy przyjętymi modelami. Obliczenia prowadzono przy użyciu programu LUSAS v.14-3 opartego na MES. Zagadnienie rozwiązywano jako dwuwymiarowe w płaskim stanie naprężenia w zakresie termo-sprężystym. Zbudowano po trzy modele z powłoką tytanową i kompozytową różniące się grubościami powłok, które wynosiły 0,$04 ; 0,1$ i $0,185 \mathrm{~mm}$.

Analizując rozkład składowej wzdłużnej naprężenia na przekroju poprzecznym złącza widać, że jej wartość nieznacznie zmienia się w powłoce, aby po przejściu przez granicę połączenia zmienić charakter na ściskający w podłożu ceramicznym (rys. 9). Wzrost grubości powłoki prowadzi do spadku rozciągających naprężeń $\delta x$ w powłoce oraz wzrostu ściskających naprężeń w podłożu ceramicznym, których ekstremum wypada pod granicą połączenia. Wprowadzenie do powłoki ceramiki $\mathrm{Al}_{2} \mathrm{O}_{3}$ w ilości $30 \%$ obj. powoduje obniżenie naprężeń rozciągających w powłoce o ok. $20 \%$ oraz zwiększenie naprężeń ściskających w podłożu ceramicznym o ok. $25 \%$. Wynika to $z$ tego, że właściwości kompozytu $\mathrm{Ti}+30 \% \mathrm{Al}_{2} \mathrm{O}_{3}$ są bardziej zbliżone do właściwości podłoża ceramicznego niż do czystego tytanu.

Na rysunku 9 naniesiono także wyniki pomiarów wygięcia powłoki z podłożem średnich naprężeń własnych w analizowanych powłokach. W przypadku powłok tytanowych o grubościach 0,1 i 0,185 mm wartości z pomiarów leżą bardzo blisko krzywych wyznaczonych z obliczeń numerycznych dla tych grubości powłok. Jedynie przy najmniejszej grubości powłoki tytanowej $(0,042 \mathrm{~mm})$ wartość naprężenia jest znacznie większa od wartości z modelu obliczeniowego. $Z$ kolei wartość zmierzonego naprężenia w powłoce kompozytowej $\mathrm{Ti}^{+} \mathrm{Al}_{2} \mathrm{O}_{3}$ o grubości $0,165 \mathrm{~mm}$ jest dużo niższa niż w modelu numerycznym. Mogą mieć na to wpływ właściwości kompozytu przyjęte do obliczeń, czy też różnica w gradiencie tych właściwości w stosunku do układu rzeczywistego, w którym podawana w czasie natrysku mieszanina proszków Ti $\mathrm{z} \mathrm{Al}_{2} \mathrm{O}_{3}$ może powodować zróżnicowaną segregację w otrzymanej powłoce.

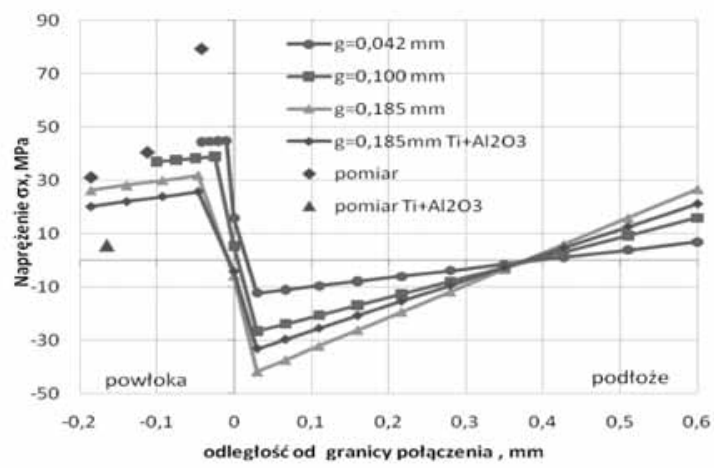

Rys. 9. Rozkład składowej naprężenia (סx) na grubości złącza (w osi modelu dla $\mathrm{x}=0$ ) dla trzech grubości powłok tytanowych oraz najgrubszej analizowanej powłoki kompozytowej $\mathrm{Ti}+30 \% \mathrm{Al}_{2} \mathrm{O}_{3}$, pojedynczymi punktami zaznaczono średnie naprężenie w powłoce otrzymane z pomiaru metodą krzywizny wygięcia

Fig. 9. The residual stress $(\delta x)$ distribution across the thickness of the joint (along $x=0$ ) for the three titanium coating thicknesses and for the thickest composite $\mathrm{Ti}+30 \% \mathrm{Al}_{2} \mathrm{O}_{3}$ coating, the marks on the graph represent average residual stress in coating obtained from curvature measurements

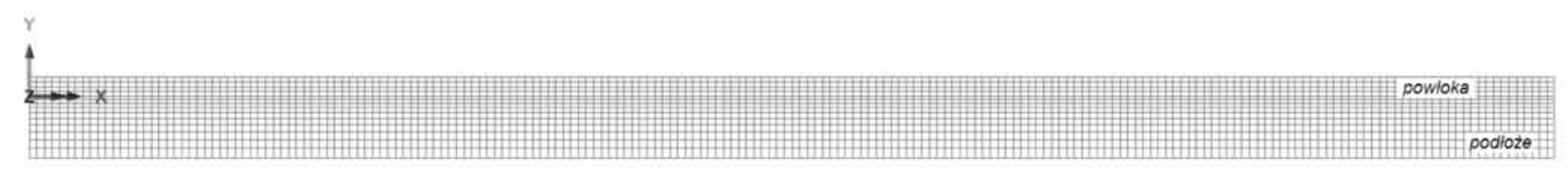

Rys. 8. Siatka elementów skończonych dla modelu powłoki nałożonej na podłoże ceramiczne

Fig. 8. The finite element mesh of the model of coating deposited onto ceramic substrate 
W obszarze połączenia przy zewnętrznej krawędzi modelu widoczna zmiana naprężenia osiowego na przekroju poprzecznym wskazuje na wysoki skok

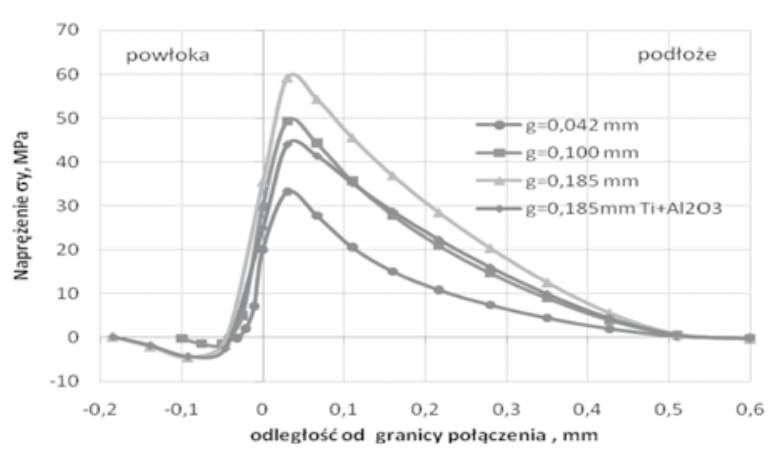

Rys. 10. Rozkład składowej osiowej naprężenia $\left(\delta_{y}\right)$ na grubości złącza (po krawędzi modelu dla $x=15$ ) dla trzech grubości powłok tytanowych oraz najgrubszej analizowanej powłoki kompozytowej $\mathrm{Ti}+30 \% \mathrm{Al}_{2} \mathrm{O}_{3}$

Fig. 10. The axial residual stress $\left(\delta_{y}\right)$ distribution across the thickness of the joint (along the model edge, $x=15$ ) for the three titanium coating thicknesses and for the thickest composite $\mathrm{Ti}+30 \% \mathrm{Al}_{2} \mathrm{O}_{3}$ coating naprężeń rozciągających $\left(\delta_{y}\right)$ na granicy powłoka-podłoże. Ze względu na liczne założenia i uproszczenia w modelach obliczeniowych rozkład tego naprężenia traktować jakościowo. Na rysunku 10 przedstawiono porównawczy rozkład naprężenia osiowego, przebiegający wzdłuż zewnętrznej krawędzi modelu.

Dla tej składowej naprężenia największe wartości rozciągające występują po stronie podłoża ceramicznego w niewielkiej odległości od linii połączenia z powłoką (ok. 0,03 mm). Wzrost grubości powłoki powoduje wzrost poziomu naprężeń osiowych w podłożu ceramicznym. Ich umiejscowienie w obszarze bliskim granicy połączenia oraz zewnętrznej krawędzi może być przyczyną odwarstwiania się powłoki od podłoża w tym miejscu, jeśli wielkość naprężeń rozciągających przekroczy wartości dopuszczalne dla ceramiki $\mathrm{Al}_{2} \mathrm{O}_{3}$. Zastosowanie materiału powłokowego kompozytowego $\left(\mathrm{Ti}+30 \% \mathrm{Al}_{2} \mathrm{O}_{3}\right)$ zamiast czystego tytanu obniża wielkość rozciągających naprężeń osiowych w tym obszarze o ok. $25 \%$ dla modelu z najgrubszą analizowaną powłoką.

\section{Podsumowanie}

Ocena stanu naprężeń własnych w natryskiwanych powłokach należy do jednego z najważniejszych problemów badawczych. W ramach pracy zbudowano stanowisko do pomiaru naprężeń własnych w powłokach na podstawie pomiaru krzywizny wygięcia próbek natryskiwanych. Wykonano wiele prób natryskiwania powłok tytanowych i kompozytowych $\mathrm{Ti}+30 \% \mathrm{Al}_{2} \mathrm{O}_{3}$ na podłożu ceramiki konstrukcyjnej $\mathrm{Al}_{2} \mathrm{O}_{3}$. Pomiary ugięcia próbek przeprowadzono dla różnych grubości powłok. Na podstawie zmierzonych wielkości ugięcia obliczono średnie naprężenie w powłoce, którego wielkość zmieniała się od prawie $80 \mathrm{MPa}$ dla najgrubszych do ok. $30 \mathrm{MPa}$ dla najcieńszych powłok tytanowych. Zastąpienie tytanu kompozytem tytanowo-ceramicznym wykazało zdecydowanie mniejsze ugięcia próbek (o ok. 20\%), także dużo niższe wartości naprężeń rozciągających w powłoce (kilka MPa). Można więc przyjąć, że zbudowany przyrząd umożliwia prawidłową rejestrację ugięcia natryskiwanych płytek. Potrzebne są jednak dalsze badania, które wymagają kolejnej modyfikacji przyrządu pomiarowego.

Przedstawione wyniki badań oraz analizy naprężeń własnych nie wyczerpują możliwości oceny badanych powłok tytanowych i tytanowo-ceramicznych nakładanych na podłoża ceramiczne. Z pewnością możliwe jest oddziaływanie na stan naprężeń w powłoce tytanowej przez optymalizację gradientu właściwości na przekroju warstwy oraz grubości powłoki.

Istotne znaczenie dla rozkładu naprężeń ma niestacjonarne pole temperatury, jakie powstaje w wyniku przewodzenia ciepła przez materiały powłoki i podłoża, a także prędkość wymiany ciepła na krawędziach złącza. Do ilościowej weryfikacji wyników obliczeń wskazane byłoby przeprowadzenie badań pola temperatury w czasie natryskiwania, zwłaszcza od strony powłoki, lub wprowadzenie czujników między powłokę i podłożem.

\section{Literatura}

[1] Clyne T.W., Gill S.C.: Residual Stresses in Surface Coatings and Their Effects on Interfacial Debonding: A Review of Recent Work, J. Thermal Spray Technology, (1996), Vol. 5(4), pp. 401-418.

[2] Stoney, G.G.: The tension of metallic films deposited by electrolysis, Proceedings of the Royal Society (London) (1909) A82, 172-175.

[3] Ohring M.: The materials science of thin films. Academic Press, New York, 1992.

[4] Mezin A.: Coating internal stress measurement through the curvature method: A geometry-based criterion delimiting the relevance of Stoney's formula. Surface \& Coatings Technology 200 (2006) 5259-5267.

[5] Goldsmith A., Waterman T.E., Hirchorn H.J.: Handbook of thermophysical properties of solid materials. New York 1961.

[6] Boyer, R., G. Welsch, E. Collings ed.: Materials Property Handbook: Titanium Alloys, ASM International, Materials Park, OH, 1994.

Badania zostały sfinansowane w ramach grantu nr N508 406037: Badania nad detonacyjnym metalizowaniem tytanem zaawansowanej ceramiki $\mathrm{Al}_{2} \mathrm{O}_{3}$ oraz $\mathrm{AIN}$. 